\title{
Sensitivity of net mass-balance estimates to near-surface temperature lapse rates when employing the degree-day method to estimate glacier melt
}

\author{
Alex S. GARDNER, Martin SHARP \\ Department of Earth and Atmospheric Sciences, University of Alberta, Edmonton, Alberta T6G 2E3, Canada \\ E-mail: alexg@ualberta.ca
}

\begin{abstract}
Glacier mass-balance models that employ the degree-day method of melt modeling are most commonly driven by surface air temperatures that have been downscaled over the area of interest, using digital elevation models and assuming a constant free air lapse rate that is often taken to be the moist adiabatic lapse rate (MALR: $-6.5^{\circ} \mathrm{C} \mathrm{km}^{-1}$ ). Air-temperature lapse rates measured over melting glacier surface are, however, consistently less steep than free air values and have been shown to vary systematically with lower-tropospheric temperatures. In this study, the implications of including a variable near-surface lapse rate in a 26 year (1980-2006) degree-day model simulation of the surface mass balance of Devon Ice Cap, Nunavut, Canada, are examined and compared with estimates derived from surface air temperatures downscaled using a constant near-surface lapse rate equal to the measured summer mean $\left(-4.9^{\circ} \mathrm{C} \mathrm{km}^{-1}\right)$ and the MALR. Our results show that degree-day models are highly sensitive to the choice of lapse rate. When compared with 23 years of surface mass-balance measurements from the northwest sector of the ice cap, model estimates are significantly better when surface air temperatures are downscaled using a modeled daily lapse rate rather than a constant lapse equal to either the summer mean or the MALR.
\end{abstract}

\section{INTRODUCTION}

The magnitude of glacier ablation depends on the energy balance at the glacier surface. For remote glacier locations, the large amounts of data required to determine this balance are often unavailable. For this reason, degree-day models (DDMs) based on the strong observed relationship between glacier melt and near-surface air temperatures are often used to estimate surface melt. Most studies that employ DDMs must downscale or interpolate climate model output and/or station observations to the area of interest. For spatially distributed models, temperature fields must be generated to reflect local conditions, which often include complex topography. This is most commonly done through the use of digital elevation models and a constant free air lapse rate (change in temperature with elevation) that is often assumed to be the moist adiabatic lapse rate $\left(6-7^{\circ} \mathrm{C} \mathrm{km}^{-1}\right)$. The problem with this approach is that temperature lapse rates measured over melting glacier surfaces have been found to be systematically less steep than the free air values (Greuell and Böhm, 1998; Braun and Hock, 2004; Hanna and others, 2005; Marshall and others, 2007). These deviations are mainly the result of temperatures over melting surfaces being fixed at $0^{\circ} \mathrm{C}$, while free atmospheric temperatures generally increase with decreasing elevation. This can generate strong temperature gradients between the surface and overlying atmosphere that increase with decreasing elevation when air temperature is above $0^{\circ} \mathrm{C}$. The strong temperature gradients drive a sensible heat flux that cools the near-surface atmosphere at lower elevations and effectively reduces the magnitude of the near-surface temperature lapse rates (Greuell and Böhm, 1998).

Recent investigations into near-surface temperature lapse rates in the Canadian High Arctic show that lapse rates vary on both seasonal and daily timescales (Marshall and others, 2007). Gardner and others (unpublished results) found that during the summer months (JJA) lapse rates vary systematically with daily mean air temperatures in the lower (i.e. $750 \mathrm{mbar}$ ) troposphere. They concluded that much of the observed covariability was due to an increase in the climate sensitivity of screen-level temperatures with increasing elevation (cf. Denby and others, 2002), where 'climate sensitivity' is defined as the change in near-surface temperature relative to a change in the free atmospheric temperature.

In this study, we examine the implications of including variable near-surface lapse rates (VLR) in DDM simulations of the surface mass balance of Devon Ice Cap, Nunavut, Canada. Surface mass-balance estimates are determined for the years $1980-2006$ and are evaluated against 23 years (1980-2003) of surface mass-balance measurements from the northwest sector of the ice cap (Koerner, 1970). These results are also compared with estimates derived using the assumption that model temperatures can be downscaled using a constant near-surface lapse rate equal to either the measured summer (JJA) mean lapse rate (GLR) or the moist adiabatic lapse rate (MALR).

\section{SITE AND DATA DESCRIPTION}

Devon Ice Cap is a large $\left(14000 \mathrm{~km}^{2}\right.$; Dowdeswell and others, 2004) dome-shaped ice mass covering much of the eastern part of Devon Island, Nunavut (Fig. 1). From 1961 to the present, the Geological Survey of Canada (GSC) has made physical measurements of the net surface mass balance $b_{\mathrm{n}}$ along a $40 \mathrm{~km}$ long stake network following a path from the glacier summit (1880 ma.s.l.) to the terminus of the Sverdrup outlet glacier in the northwest sector of the ice cap (Fig 1; Koerner, 2005). Previous estimates of surface mass balance (mm w.e. $\mathrm{a}^{-1}$ ) for the main ice cap (excluding the southwest arm) vary greatly between study periods: -76 50 (1961-66 (Koerner, 1970)), $-30 \pm 60$ (1963-2000 


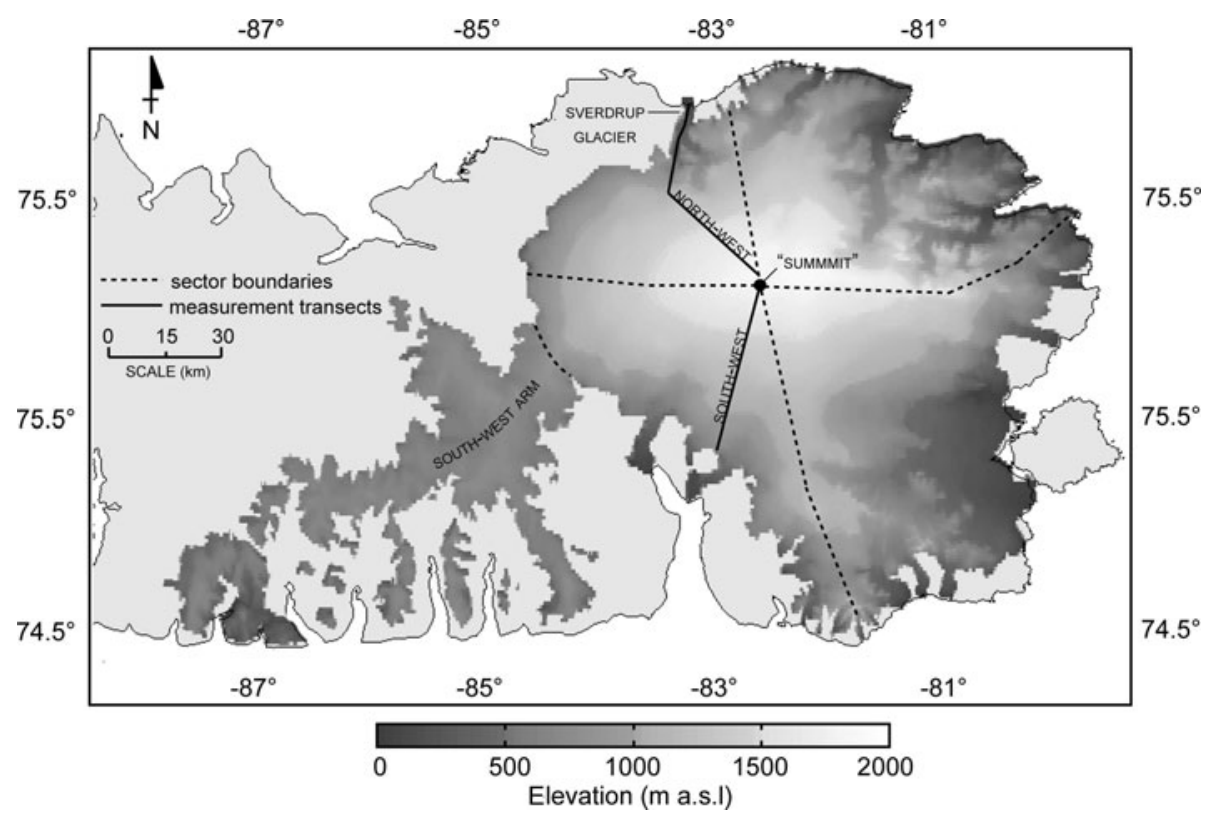

Fig. 1. Devon Ice Cap shown with region boundaries and transects along which field measurements have been taken.

(Mair and others, 2005)) and $+28 \pm 70$ (1996 (Shepherd and others, 2007)).

Continuous meteorological measurements have been made on the ice cap since 1997, with as many as 7 automatic weather stations and 13 temperature sensors operating along 2 transects in 2004 (Fig. 1). Near-surface temperature lapse rates derived from these transects show strong linear relationships $(r=0.72)$ with summit elevation temperatures (Fig. 2)

\section{MASS-BALANCE MODEL \\ Glacier melt}

The Degree-Day glacier Mass Balance model (DDM) determines the daily quantity of melt $m_{t}(\mathrm{~mm}$ w.e.) as a function of the mean daily air temperature $T_{t}\left({ }^{\circ} \mathrm{C}\right)$ using a factor of proportionality referred to as the degree-day factor DDF $\left(\mathrm{mm} \mathrm{d}^{-1}{ }^{\circ} \mathrm{C}\right)$ :

$$
\begin{array}{ll}
m_{t}=\mathrm{DDF} \cdot T_{t} & T_{t} \geq 0{ }^{\circ} \mathrm{C} \\
m_{t}=0 & T_{t}<0{ }^{\circ} \mathrm{C} .
\end{array}
$$

Owing to differences in the surface energy-balance characteristics of snow and ice (including albedo, shortwave penetration, thermal conductivity and surface roughness), separate values are used for snow $\left(D_{D} F_{s}\right)$ and ice $\left(D D F_{i}\right)$. Reported factors vary greatly from study to study, depending on local variations in the surface energy balance (albedo, incoming solar radiation, surface roughness, wind speed and air temperature), how melt was determined (measured or modeled), the time period over which the study was conducted, and how air temperatures were determined (daily or hourly mean). Hock (2003) provides a comprehensive review of the temperature-index melt-modeling method. For this study we adopt the values $D_{D D F}=3.3 \mathrm{~mm} \mathrm{~d}^{-1}{ }^{\circ} \mathrm{C}$ and $\mathrm{DDF}_{\mathrm{i}}=8.2 \mathrm{~mm} \mathrm{~d}^{-1}{ }^{\circ} \mathrm{C}$, which are the mean values determined by Braithwaite (1995) at two locations (880 and $790 \mathrm{ma.s.l}$.) on the Greenland ice sheet. Braithwaite (1995) obtained these values through the use of an energybalance model over a 6 year period and they agree well with factors determined from stake measurements made at the same locations. These are the same factors used by Shepherd and others (2007) to model melt over Devon Ice Cap for 1996, and compare with $D_{D D F}=4$ and $\mathrm{DDF}_{\mathrm{i}}=6-14 \mathrm{~mm} \mathrm{~d}^{-1}{ }^{\circ} \mathrm{C}$ used by Mair and others (2005) to model melt over the ice cap for the years 1963-2000.

\section{Surface air temperature and downscaling}

Daily mean surface air temperatures were downscaled to the entire ice cap from summit elevation temperatures using both modeled mean daily and assumed constant lapse rates and a $30^{\prime \prime} \times 30^{\prime \prime}$ digital elevation model (DEM; Canada3D: available from Natural Resources Canada). Daily mean $2 \mathrm{~m}$ air temperatures from the North American Regional Reanalysis (NARR; Mesinger and others, 2006) were extracted for the model gridcell centered on the summit of the ice cap and were corrected for a mean summer (JJA) temperature offset of $+4^{\circ} \mathrm{C}$ relative to 8 years (1997-2004) of air-temperature measurements from an on-glacier weather station located near the summit of the ice cap. The $4^{\circ} \mathrm{C}$ offset in the NARR air temperature is partly due to the coarse resolution of the NARR model topography, which models the maximum elevation of Devon Ice Cap at an elevation $400 \mathrm{~m}$ lower than the true summit elevation. After adjusting for the mean difference, measured and modeled summer daily mean summit air temperatures show good agreement

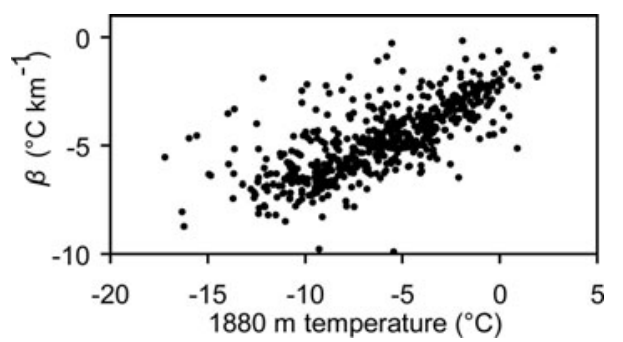

Fig. 2. 1998-2004 average daily summer (JJA) lapse rates $\beta$ for the northwest transects plotted against respective mean daily summit air temperatures. 


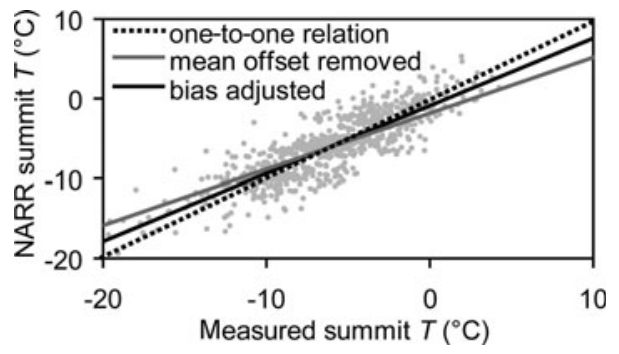

Fig. 3. NARR bias-adjusted summer (JJA) daily summit air temperatures $(T)$ plotted against measured summit temperatures $(1880 \mathrm{~m})$. The two solid lines show the linear regression relationship between NARR and measured summit temperatures before (grey: $r=0.86$ ) and after (black: $r=0.85$ ) the temperatures have been adjusted for overly warm temperatures on relatively cool days and overly cool temperatures on relatively warm days.

$(r=0.86)$ except for systematic underestimations of maximum and overestimation of minimum summer summit temperatures. To correct for this bias, we add or subtract corrections drawn randomly from a normal distribution with a range of $0-2^{\circ} \mathrm{C}$ to all NARR summer temperatures above $-4.5^{\circ} \mathrm{C}$ and below $-7.5^{\circ} \mathrm{C}$, respectively (Fig. 3). Surface air temperatures were generated for both ablation season days and non-ablation season days in order to determine mean annual and winter temperatures needed for the calculation of maximum meltwater refreeze amounts, which are discussed below.

To investigate the impact on mass balance of using different near-surface temperature lapse rates $\beta$ to downscale air temperatures, three separate surface air-temperature fields were generated. The first was generated using a near-surface lapse rate equal to the moist adiabatic lapse rate $\left(\bar{\beta}_{\mathrm{MALR}}=-6.5^{\circ} \mathrm{C} \mathrm{km}^{-1}\right)$, the second using mean measured lapse rates $\left(\bar{\beta}_{\mathrm{MMLR}}=-4.9^{\circ} \mathrm{C} \mathrm{km}^{-1}\right)$ for all days during the ablation season (15 May-15 September) and all winter days (16 September-14 May: $\bar{\beta}_{M M L R_{w}}=-3.3^{\circ} \mathrm{C} \mathrm{km}^{-1}$ ), and the third using a modeled variable daily lapse rate $\beta_{\mathrm{VLR}}\left({ }^{\circ} \mathrm{C} \mathrm{km}^{-1}\right)$ during the ablation season and $\bar{\beta}_{\mathrm{MMLR}}$ in winter. $\beta_{\mathrm{VLR}}$ was estimated using the lapse-rate equation developed from over 10 years of screen-level air-temperature measurements made over Devon Ice Cap (Gardner and others, unpublished results):

$$
\beta_{\mathrm{VLR}}=0.2 T_{750}-4.9,
$$

where $T_{750}$ is the 3 day running mean of the daily anomaly (summer mean removed) in NARR 750 mbar temperature. $T_{750}$ was derived from a six-gridcell domain $(64 \times 86 \mathrm{~km})$ centered over the ice cap. To illustrate the range in variability of $\beta_{\mathrm{VLR}}$, mean daily summit temperatures are plotted with $\beta_{\mathrm{VLR}}$ for the highest (1986: Fig. 4a) and lowest (2001; Fig. 4b) measured mass-balance years in the study period. On 26 July 2001, when temperatures peaked at $5^{\circ} \mathrm{C}$, $\beta_{\mathrm{VLR}}=-3^{\circ} \mathrm{C} \mathrm{km}^{-1}$. On this day, downscaling summit temperatures with $\beta_{\mathrm{VLR}}$ results in sea-level temperatures that are $4^{\circ} \mathrm{C}$ and $7^{\circ} \mathrm{C}$ cooler than temperatures downscaled using $\bar{\beta}_{\text {MMLR }}$ and $\bar{\beta}_{\text {MALR, respectively. This represents }}$ $\sim 30-55 \mathrm{~mm}$ w.e. less ice melt for this day.

The three model runs forced with mean daily airtemperature fields downscaled using $\beta_{\mathrm{VLR}}, \bar{\beta}_{\mathrm{MMLR}}$ and $\bar{\beta}_{\text {MALR }}$ are referred to throughout this paper as the VLR, MMLR and MALR runs, respectively.

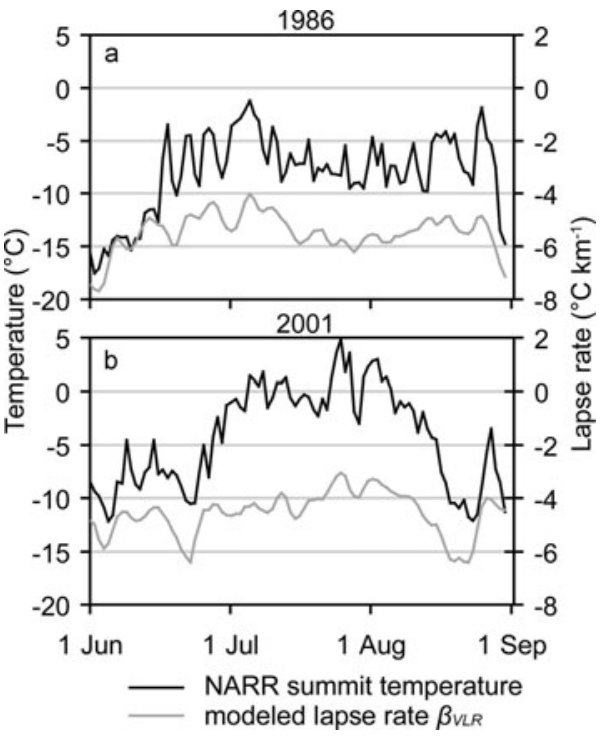

Fig. 4. NARR summit elevation temperatures plotted with variable modeled daily lapse rates $\beta_{\mathrm{VLR}}$ for representatively (a) cold and (b) warm years. Modeled lapse rates are less steep when temperatures are anomalously warm, and steeper when temperatures are anomalously cold.

\section{Precipitation}

Daily precipitation was derived from the NARR and corrected for a mean over-precipitation bias of $100 \mathrm{~mm}$ w.e. $\mathrm{a}^{-1}$, which was determined from the comparison of NARR mean annual precipitation at the summit with the net mass balance measured at the same location for the years 1979-2003 (personal communication from R.M. Koerner). Taking point values at the center of the NARR gridcells, the bias-adjusted coarse-resolution $(3 \times 32 \mathrm{~km})$, NARR daily precipitation fields were linearly interpolated based on horizontal distance to match the resolution of the DEM $(\sim 200 \times 1000 \mathrm{~m})$. The phase of the daily precipitation $P_{t}$ (mmw.e.) was determined at each gridcell based on the estimated mean daily gridcell air temperature $T_{t}$ :

$$
\begin{array}{ll}
P_{t}=\text { snow } & \mathrm{T}_{\mathrm{t}} \leq 0^{\circ} \mathrm{C} \\
P_{t}=\text { rain } & \mathrm{T}_{\mathrm{t}}>0^{\circ} \mathrm{C} .
\end{array}
$$

Here we have chosen the critical surface temperature for phase change as $0^{\circ} \mathrm{C}$ (Bassford and others, 2006). Other studies use values as high as $2^{\circ} \mathrm{C}$ (Oerlemans, 1991). Using a critical value of $2{ }^{\circ} \mathrm{C}$ would increase net mass-balance estimates of Devon Ice Cap on average by $40 \pm 14 \mathrm{~mm}$ w.e. relative to the value used here. At the summit of the ice cap, the standard error of the interpolated precipitation was determined as $40 \mathrm{~mm}$ w.e. $\mathrm{a}^{-1}$.

\section{Refreezing of meltwater}

All liquid water (melt or rain) generated within any gridcell in a given year is assumed to refreeze in that gridcell until the volume of refrozen water $F=F_{\text {max }}$, where $F_{\max }$ is the maximum amount of refreeze that can occur in that cell. Once the liquid water exceeds $F_{\max }$, all additional rain or melt generated in that year is assumed to leave the glacier as runoff. We use the term 'refreeze' to refer to the total amount of meltwater and rain that refreezes on the glacier during a given mass-balance year and can re-melt later in that year 

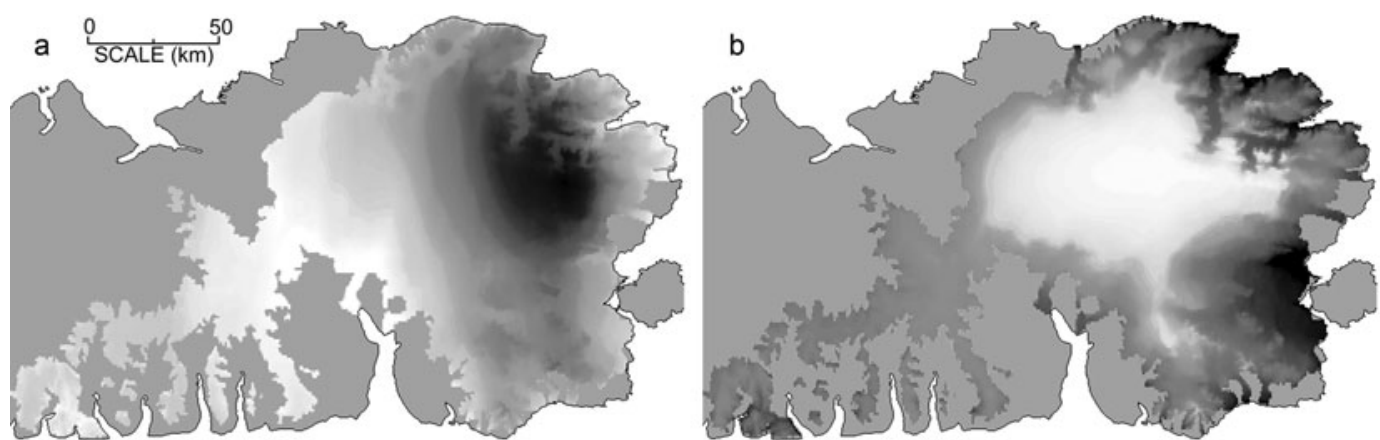

snow (mm w.e. $\left.\mathrm{a}^{-1}\right)$
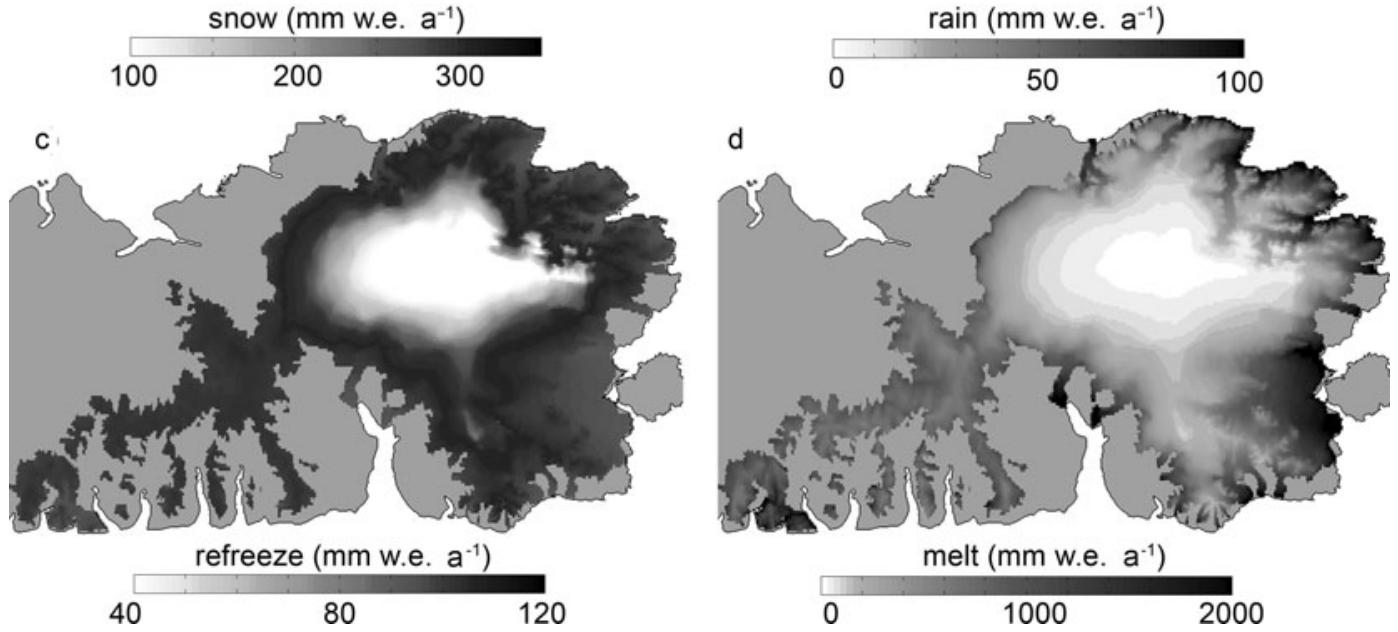

Fig. 5. Mean annual snow (a), rain (b), meltwater refreeze (c) and melt (d) for Devon Ice Cap averaged over the years 1980-2006. Values determined from the VLR model run (see text for details).

and run off; the term 'internal accumulation' refers to the amount of water that refreezes, does not run off, and remains on the glacier into the following mass-balance year. There is no communication between gridcells, so meltwater only affects refreeze and internal accumulation quantities of the cell in which that meltwater is generated.

$F_{\max }$ was determined at each gridcell using the method proposed by Wright and others (2007). This method determines $F_{\max }$ based on a simplified estimate of the total amount of energy required to change the temperature profile of the upper 10-15 $\mathrm{m}$ of the glacier from an end-of-winter temperature profile to a post-refreezing profile:

$$
F_{\max }=\frac{c_{\mathrm{i}} d_{\mathrm{i}}}{2 L_{\mathrm{f}}}\left[\left(1-\frac{\pi}{2}\right) \bar{T}_{\mathrm{a}}-\bar{T}_{\mathrm{w}}\right],
$$

where $c_{\mathrm{i}}$ is the specific heat capacity of ice at $0^{\circ} \mathrm{C}$ $\left(2097 \mathrm{~J} \mathrm{~kg}^{-1}{ }^{\circ} \mathrm{C}^{-1}\right), d_{\mathrm{i}}$ is the maximum depth to which the annual temperature cycle penetrates, $L_{f}$ is the latent heat of fusion for water $\left(333.5 \mathrm{~kJ} \mathrm{~kg}^{-1}\right), \bar{T}_{\mathrm{a}}$ is the mean annual air temperature and $\bar{T}_{\mathrm{w}}$ is the mean winter temperature (here taken as the mean temperature outside of the ablation season). On Devon Ice Cap the annual temperature cycle penetrates to $\sim 10-15 \mathrm{~m}$ depth. Using this value for $d_{i}$ results in $F_{\max }$ values which are much too large (>1000 mm w.e.). We instead set $d_{\mathrm{i}}=1 \mathrm{~m}$, which gives mean $F_{\max }$ values at the summit of the ice cap that are $\sim 60 \%(130 \mathrm{~mm})$ of the annual snowfall, the value often used for the upper threshold for meltwater refreezing on the Greenland ice sheet (Reeh, 1991), and is supported by field measurements made near the equilibrium-line altitude of the Greenland ice sheet (Braithwaite and others, 1994).

\section{RESULTS}

\section{Mass-balance components}

Average (1980-2006) annual snowfall, rainfall, refreeze and melt generated from the VLR model run are shown in Figure 5. Similar spatial patterns in the four mass-balance components are seen in all three model runs, but magnitudes vary as all components are dependent on the surface air temperature. Averaged over the entire ice cap (including the southwest arm) for the period of study, mean annual snowfall $\left(156 \pm 11 \mathrm{~mm}\right.$ w.e. $\left.\mathrm{a}^{-1}\right)$, rainfall $\left(43 \pm 10 \mathrm{~mm}\right.$ w.e. $\left.\mathrm{a}^{-1}\right)$ and meltwater refreeze $\left(90 \pm 7 \mathrm{~mm}\right.$ w.e. $\left.\mathrm{a}^{-1}\right)$ vary little between model runs, with slightly lower $\left(20 \mathrm{~mm}\right.$ w.e. $\left.\mathrm{a}^{-1}\right)$ snowfall and slightly higher $\left(20 \mathrm{~mm}\right.$ w.e. $\left.\mathrm{a}^{-1}\right)$ rainfall amounts for the MALR run due to a higher frequency of above-zero temperatures in that run. There are, however, large differences in melt quantities, with mean annual estimates of $730 \pm 250,960 \pm 350$ and $1840 \pm 440 \mathrm{~mm}$ w.e. $\mathrm{a}^{-1}$ for the VLR, MMLR and MALR model runs, respectively. Because the model runs differ greatly in both the melt amounts and the altitudes at which melt occurs, the three model runs produce very different internal accumulation distributions (Fig. 6) and thicknesses $\left(8,12\right.$ and $3 \mathrm{~mm}$ w.e. $\mathrm{a}^{-1}$ for the VLR, MMLR and MALR model runs, respectively).

\section{Comparison with measurements (northwest sector)}

Modeled point-location net mass-balance $\left(b_{n}\right)$ estimates were extracted from the model output along the GSC's northwest transect and compared with their respective stake measurements at $100 \mathrm{~m}$ elevation intervals from 150 to $1750 \mathrm{~m}$ a.s.l. for the period of available data (1980-2003; 

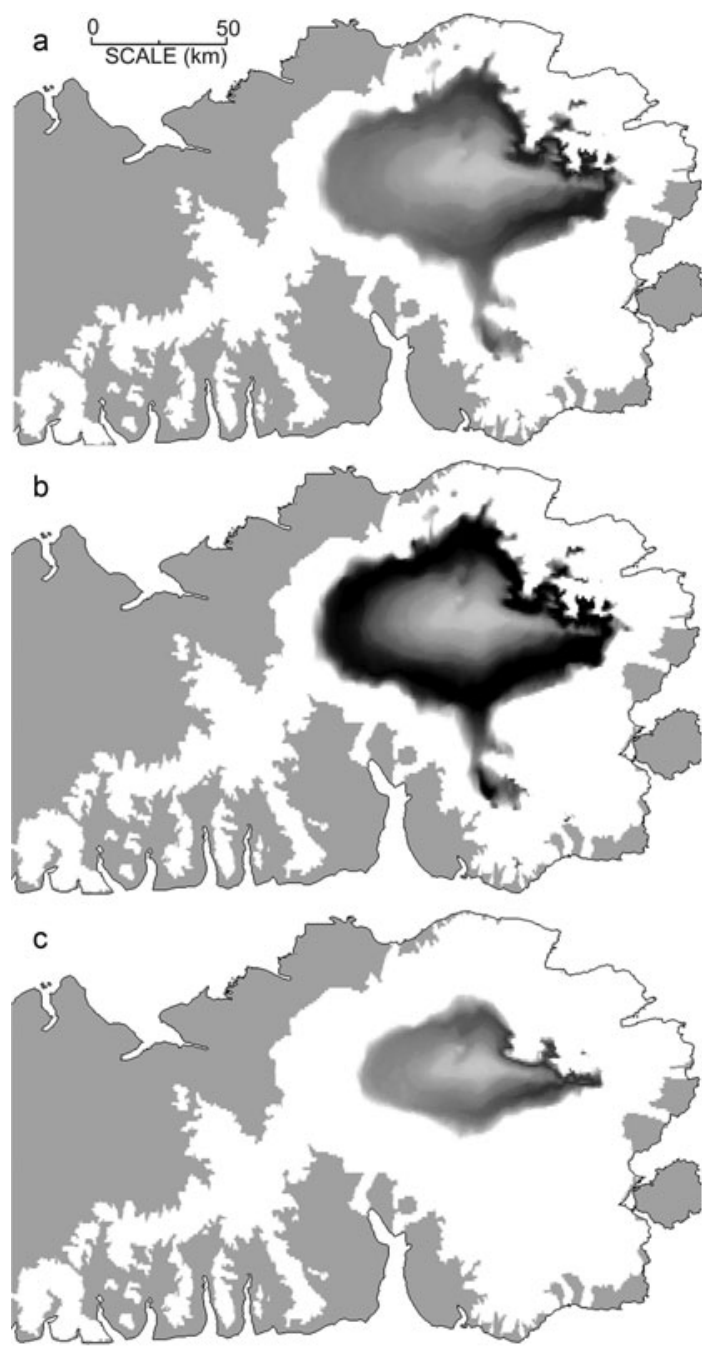

internal accumulation ( $\mathrm{mm}$ w.e. $\left.\mathrm{a}^{-1}\right)$

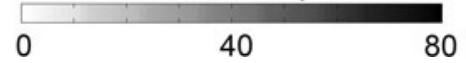

Fig. 6. Annual mean internal accumulation formation estimated from the (a) VLR, (b) MMLR and (c) MALR model runs.

personal communication from R.M. Koerner) (Fig. 7). All model estimates are similar and agree well with the stake measurements at elevations above $1450 \mathrm{~m}$, but they diverge with decreasing elevation as estimated melt quantities increase. At $150 \mathrm{~m}$, all model runs significantly overestimate melt quantities relative to measurements by as much as $2800 \mathrm{~mm}$ for the MALR run. Overall, the VLR and MMLR

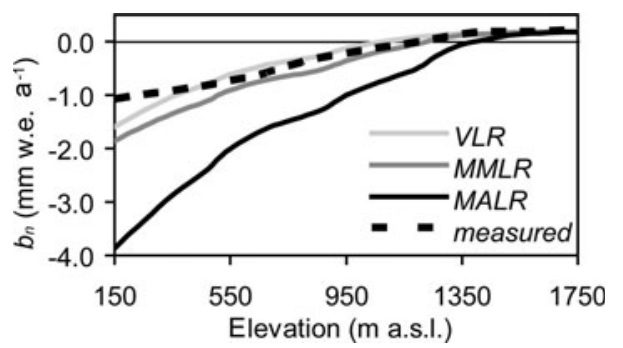

Fig. 7. Average (1980-2001) annual point-location net massbalance $\left(b_{\mathrm{n}}\right)$ model estimates extracted at $100 \mathrm{~m}$ intervals along the northwest transect shown with respective mass-balance stake network measurements.

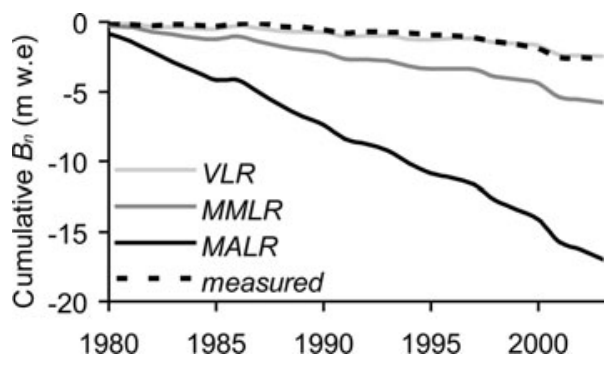

Fig. 8. Modeled cumulative surface mass balance $B_{\mathrm{n}}$ for the northwest sector of Devon Ice Cap plotted with estimates derived from measurements.

model runs significantly outperform the MALR model run, with 23 year mean \pm standard errors averaged across all elevations of $+25 \pm 260$ and $-140 \pm 340 \mathrm{~mm}$ w.e. $\mathrm{a}^{-1}$, respectively, compared with $-880 \pm 920 \mathrm{~mm}$ w.e. $\mathrm{a}^{-1}$ for the MALR. Using the sector boundaries outlined by Koerner (1970), cumulative annual net mass balances $B_{\mathrm{n}}$ for the three model runs were estimated for the northwest sector of the ice cap and are shown together with an estimate derived from stake measurements in Figure 8. $B_{\mathrm{n}}$ estimates vary greatly between model runs with mean \pm standard errors of $9 \pm 120,-113 \pm 150,-577 \pm 223 \mathrm{~mm}$ w.e. $\mathrm{a}^{-1}$ for the VLR, MMLR and MALR runs relative to measured values. The VLR model run produces $B_{\mathrm{n}}$ that are close to measured values, with a 1980-2003 cumulative difference of only $0.2 \mathrm{~m}$ w.e.

\section{Net mass balance of Devon Ice Cap}

Annual $B_{\mathrm{n}}$ values were calculated for the main portion of the ice cap (southwest arm excluded: $12100 \mathrm{~km}^{2}$ (Dowdeswell and others, 2004)) and are shown in Figure 9. The MALR model run produces mass-balance values that are, on average, 4 times more negative than values determined from the VLR model run and $\sim 2.5$ times more negative than values determined from the MMLR run. During more positive mass-balance years (e.g. 1986 and 2004) there is good agreement between the VLR and MMLR model runs, but the differences are larger during more negative years (e.g. 2001 and 2006). This is because the total annual positive degree-days (PDDs) for the two runs are most similar when lower-tropospheric temperatures are seasonally low, and most different when temperatures are seasonally warm (i.e. during high melt years). For the whole ice cap (southwest arm included), $B_{\mathrm{n}}$ values are $24-41 \%$ more negative than for the main ice cap because the entire southwest arm lies below $900 \mathrm{~m}$ and often lies completely within the ablation zone (Fig. 10).

Using perturbed historical accumulation measurements and a constant lapse rate of $-4.6^{\circ} \mathrm{C} \mathrm{km}^{-1}$ (mean 2001 lapserate measure over Devon Ice Cap) to extrapolate sea-level temperature data from the International Arctic Buoy Program over different sectors of the ice cap, Shepherd and others (2007) estimated the 1996 net mass balance for the main ice cap to be $28 \mathrm{~mm}$ w.e. This value is 42,140 and $730 \mathrm{~mm}$ w.e. larger than 1996 estimates computed using the VLR, MMLR and MALR, respectively. We attribute most of the difference between the VLR model run and this estimate to the slightly higher $(12 \mathrm{~mm}$ w.e.) snowfall estimate used by Shepherd and others (2007), which results in both greater net accumulation at higher elevations and less melt at lower elevations, 


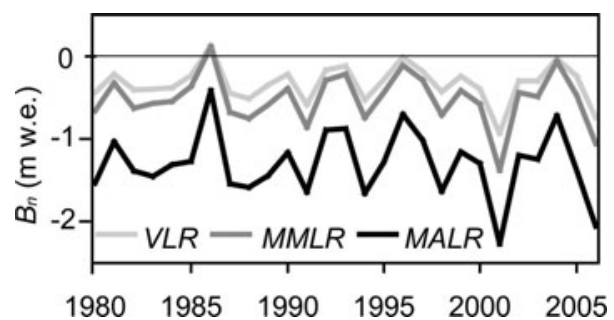

Fig. 9. Net mass balance $B_{\mathrm{n}}$ for the main Devon Ice Cap (southwest arm excluded) for all three model runs.

since snow has a lower DDF than ice. The differences between the estimate of Shepherd and others (2007) and the estimates generated using MMLR and MALR are attributed to an overestimation of surface air temperatures in the MMLR and MALR simulations (much higher melt and slightly lower snowfall) due to the use of overly steep lapse rates.

Based on our comparisons with independent model estimates of the 1996 net glacier mass balance for the main ice cap and 24 years of measurements made along the northwest stake transect, we take the VLR model results as the best estimate of surface mass balance. We estimate that the main ice cap lost an average of $333 \pm 120 \mathrm{~mm}$ w.e. $\mathrm{a}^{-1}$ over the period 1980-2006, where the error associated with this estimate is taken to be the standard error of the modeled, relative to measured, net mass balance for the northwest sector.

\section{DISCUSSION AND CONCLUSION}

The use of different air-temperature lapse rates in the downscaling of surface air temperatures over Devon Ice Cap has a large impact on estimates of glacier mass balance produced with the degree-day method. Using the moist adiabatic lapse rate $\left(-6.5^{\circ} \mathrm{Cm}^{-1}\right)$ to downscale summit elevation temperatures over the ice cap generates net mass-balance estimates that are 4 times more negative than estimates made using a modeled variable lapse rate and $\sim 2.5$ times more negative than estimates made using a mean measured summer lapse rate. Over the main ice cap, mass-balance estimates made from temperature fields downscaled with the mean measured summer lapse rate overestimate melt by $\sim 180 \pm 100 \mathrm{~mm}$ w.e. $\mathrm{a}^{-1}$ on average relative to estimates made from temperature fields downscaled using a modeled variable lapse rate. During more positive mass-balance years, model results generated using the two methods agree closely, but they diverge by as much as $550 \mathrm{~mm}$ w.e. $\mathrm{a}^{-1}$ during the most negative mass-balance years.

When the DDM is forced with surface air-temperature fields downscaled using modeled variable daily lapse rates, it produces estimates of net surface mass balance that agree well $(9 \pm 120 \mathrm{~mm})$ with the 23 years of measurements made along the northwest transect. This same method produces a 1996 estimate of net mass balance for the main ice cap that agrees closely (42 mm w.e. higher) with the previous 1996 estimate made by Shepherd and others (2007). However, forcing the model with these surface air temperatures only results in a $25 \%\left(80 \mathrm{~mm}\right.$ w.e. $\left.\mathrm{a}^{-1}\right)$ improvement in the standard error of point-location net mass-balance estimates relative to estimates made from temperature fields downscaled using a mean summer lapse rate. Like all DDMs, model results are highly sensitive to the choice of degree-day

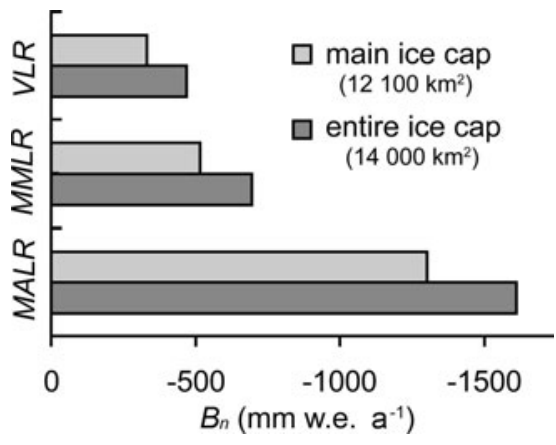

Fig. 10. Model run estimates of mean annual net mass balance $B_{\mathrm{n}}$ for the main (excluding southwest arm) and whole Devon Ice Cap.

factors. While we have chosen not to tune the model using the degree-day factors, model root-mean-square errors similar to those achieved when the DDM is forced with a variable lapse rate could be achieved by adjusting the degree-day factor for ice to $\sim 4.5-6.5$ and $\sim 2-3.5 \mathrm{~mm}$ w.e. $\mathrm{d}^{-1}$ when employing the mean measured summer lapse rate and the moist adiabatic lapse rate, respectively. When comparing against previously published values (Hock, 2003), a degreeday factor $<5.0 \mathrm{~mm}$ w.e. $\mathrm{d}^{-1}$ for ice is unrealistic. Therefore, the model can only be tuned with a realistic degree-day factor for ice to produce comparable results to those achieved using the untuned variable lapse rate when the mean measured summer lapse rate is employed. The root-meansquare error across all three models is relatively insensitive to degree-day factor for snow between 2 and $6 \mathrm{~mm}$ w.e. $\mathrm{d}^{-1}$.

Our best estimate of the net surface mass balance of the main ice cap over the years 1980-2006 is $-330 \pm 120 \mathrm{~mm}$ w.e. $\mathrm{a}^{-1}$, which is much lower than previous estimates of $-76 \pm 50$ (1961-66 (Koerner 1970)), $-130 \pm 60$ (1963-2000 (Mair and others, 2005)) and $28 \pm 70$ mmw.e. $\mathrm{a}^{-1}$ (1996 (Shepherd and others, 2007)). The more negative model estimate can be attributed to differences in mean summer conditions between the different time periods for which estimates have been derived, and to large uncertainties in estimated accumulation rates due to large spatial variations in snowfall (Koerner, 1966), which are poorly reproduced by the $32 \times 32 \mathrm{~km}$ resolution NARR output. In particular, total accumulation amounts measured by Koerner (1966) were found to be 2-6 times larger for the southeast (largest sector) than for the northwest sector of the ice cap and are nearly equivalent to the regridded NARR model output.

In conclusion, DDMs are highly sensitive to the choice of lapse rate when models are forced with downscaled temperature fields. For the DDM used in this study, use of a variable daily lapse rate estimated from lower-tropospheric (750 mbar) temperatures to downscale surface air temperatures gives significantly better mass-balance estimates than a constant lapse rate equal to either the summer mean or the moist adiabatic lapse rate.

\section{ACKNOWLEDGEMENTS}

This work was supported by the Natural Sciences and Engineering Research Council (NSERC Canada) (through Discovery, Northern Supplement and Equipment Grants to M. Sharp, and an Alexander Graham Bell Canada Graduate Scholarship to A.S. Gardner), the Canadian Foundation for 
Climate and Atmospheric Sciences through the Polar Climate Stability Network, Environment Canada through the Cryosphere System in Canada Project (CRYSYS), the Northern Scientific Training Program (Indian and Northern Affairs Canada), the Institute for Geophysical Research and Circumpolar Boreal Alberta Research Grant fund (University of Alberta) and by the Alberta Ingenuity Fund (through scholarships to A.S. Gardner). We thank the late R.M Koerner for making available surface mass-balance and temperature datasets.

\section{REFERENCES}

Bassford, R.P., M.J. Siegert and J.A. Dowdeswell. 2006. Quantifying the mass balance of ice caps on Severnaya Zemlya, Russian High Arctic. III: Sensitivity of ice caps in Severnaya Zemlya to future climate change. Arct. Antarct. Alp. Res., 38(1), 21-33.

Braithwaite, R.J. 1995. Positive degree-day factors for ablation on the Greenland ice sheet studied by energy-balance modelling. J. Glaciol., 41(137), 153-160.

Braithwaite, R.J., M. Laternser and W.T. Pfeffer. 1994. Variations of near-surface firn density in the lower accumulation area of the Greenland ice sheet, Pâkitsoq, West Greenland. J. Glaciol., 40(136), 477-485.

Braun, M. and R. Hock. 2004. Spatially distributed surface energy balance and ablation modelling on the ice cap of King George Island (Antarctica). Global Planet. Change, 42(1-4), 45-58.

Denby, B., W. Greuell and J. Oerlemans. 2002. Simulating the Greenland atmospheric boundary layer. Part II: Energy balance and climate sensitivity. Tellus A, 54(5), 529-541.

Dowdeswell, J.A., T.J. Benham, M.R. Gorman, D. Burgess and M. Sharp. 2004. Form and flow of the Devon Island ice cap, Canadian Arctic. J. Geophys. Res., 109(F2), F02002. (10.1029/ 2003JF000095.)

Greuell, W. and R. Böhm. 1998. $2 \mathrm{~m}$ temperatures along melting mid-latitude glaciers, and implications for the sensitivity of the mass balance to variations in temperature. J. Glaciol., 44(146), 9-20.

Hanna, E., P. Huybrechts, I. Janssens, J. Cappelen, K. Steffen and A. Stephens. 2005. Runoff and mass balance of the Greenland ice sheet: 1958-2003. J. Geophys. Res., 110(D13), D13108. (10.1029/2004JD005641.)

Hock, R. 2003. Temperature index melt modelling in mountain areas. J. Hydrol., 282(1-4), 104-115.

Koerner, R.M. 1966. Accumulation on the Devon Island ice cap, Northwest Territories, Canada. J. Glaciol., 6(45), 383-392.

Koerner, R.M. 1970. The mass balance of the Devon Island ice cap, Northwest Territories, Canada, 1961-66. J. Glaciol., 9(57), 325-336.

Koerner, R.M. 2005. Mass balance of glaciers in the Queen Elizabeth Islands, Nunavut, Canada. Ann. Glaciol., 42, 417-423.

Mair, D., D. Burgess and M. Sharp. 2005. Thirty-seven year mass balance of Devon Ice Cap, Nunavut, Canada, determined by shallow ice coring and melt modelling. J. Geophys. Res., 110(F1), F01011. (10.1029/2003JF000099.)

Marshall, S.J., M.J. Sharp, D.O. Burgess and F.S. Anslow. 2007. Near-surface-temperature lapse rates on the Prince of Wales Icefield, Ellesmere Island, Canada: implications for regional downscaling of temperature. Int. J. Climatol., 27(3), 385-398.

Mesinger, F. and 18 others. 2006. North American regional reanalysis. Bull. Am. Meteorol. Soc., 87(3), 343-360.

Oerlemans, J. 1991. A model for the surface balance of ice masses: Part 1. Alpine glaciers. Z. Gletscherkd. Glazialgeol., 27, 63-83.

Reeh, N. 1991. Parameterization of melt rate and surface temperature on the Greenland ice sheet. Polarforschung, 59(3), 113-128.

Shepherd, A., Z. Du, T.J. Benham, J.A. Dowdeswell and E.M. Morris. 2007. Mass balance of Devon Ice Cap, Canadian Arctic. Ann. Glaciol., 46, 249-254.

Wright, A.P., J.L. Wadham, M.J. Siegert, A. Luckman, J. Kohler and A.-M. Nuttall. 2007. Modeling the refreezing of meltwater as superimposed ice on a high Arctic glacier: a comparison of approaches. J. Geophys. Res., 112(F4), F04016. (10.1029/ 2007JF000818.) 